\title{
Urbane scholarship: studying Africa, understanding the world ${ }^{1}$
}

\author{
Elísio Macamo
}

\section{Welcome and introduction from Alcinda Honwana}

\begin{abstract}
On behalf of the International African Institute, I would like to welcome you all to this year's Lugard Lecture. The Institute established the lecture in 1948 in honour of its founding chairman, Lord Lugard. A few years ago, the Council had a lively debate on whether to change the name of the lecture given Lord Lugard's colonial ties. While there were divergent views, the Council came to the conclusion that it was important not to try to erase our ancestors or our history but to acknowledge the past, face its dark side, and engage it critically to advance new perspectives, new ways of understanding ourselves and the world around us. Indeed, over the years, distinguished scholars developing innovative and cutting-edge research and analysis in the field of African Studies have delivered remarkable Lugard lectures on a variety of topics addressing critical challenges of our time. And it is with great pleasure that I introduce you today to my fellow countryman and colleague, Professor Elísio Macamo, as the 2017 Lugard lecturer. Elísio, meu irmão, e' de facto um grande prazer apresentar-te nesta ocasião tão especial. Born in the city of Xai-Xai in Southern Mozambique, Professor Macamo studied in Maputo where he concluded a diploma in language and translation, and then proceeded to earning an MA degree in translation and interpreting from Salford University in the UK, and another MA in sociology and social policy from the University of North London. He then continued his graduate studies in Germany, receiving a $\mathrm{PhD}$ and a 'Habilitation' in sociology from the University of Bayreuth in 1997 and 2009 respectively. Professor Macamo's distinguished scholarship made him rise through the ranks and he is currently Director of the African Studies Centre, and Head of the Department of Social Sciences in the Faculty of Humanities and Social Sciences at the University of Basel. Before joining the University of Basel, he taught development sociology at Bayreuth and was one of the founding members of the Bayreuth International Graduate School of African Studies. Moreover, Elísio Macamo has been a visiting professor at universities in Germany, Portugal, Mozambique, South Africa and Brazil, and a member of several academic bodies, including the Council for the Development of Social Science Research in Africa (CODESRIA), the German and Swiss Associations of African Studies as well as the International African Institute. He is also co-editor of the African Sociological Review and the Revista Angolana de Sociologia, amongst others. Elísio's outstanding contributions to academia are seen in his extensive publications. Drawing inspiration from
\end{abstract}

\footnotetext{
Elísio Macamo is Professor of African Studies at the University of Basel, where he is both the Director of the Centre for African Studies and Head of the Social Science Department. He was born and raised in Mozambique and studied sociology in London and Bayreuth. He has been a member of the Council of the International African Institute since 2015. Email: elisio. macamo@unibas.ch

${ }^{1}$ This article is a version for publication of the lecture given as the IAI-sponsored 'Lugard Lecture' held on 29 June 2017 during the European Conference on African Studies (ECAS) at the University of Basel, Switzerland. It was introduced by Alcinda Honwana, Chair of the Council of the International African Institute, whose remarks are included with the article. An audio recording is available at $<$ https://www.youtube.com/watch?v=tooclmpUmnc\&feature=youtu.be $>$.
}

(C) International African Institute 2018 
both postcolonial theorists and sociology classics, he takes a special interest in phenomenological and interpretive approaches to empirical social research, and has written on issues as diverse as modernity, religion, development policy, risk, disasters, social movements and political violence as well as African philosophy. Elísio is committed to the development of African Studies by addressing the challenges posed by cross-cultural and cross-disciplinary research. And, as he pointed out in a recent interview: 'My main concern is to find ways to reflect about how to produce knowledge; it is a philosophical and an epistemological concern, because it is really about theories of knowledge.' Indeed, in his lecture today, entitled 'Urbane Scholarship', Elísio will eloquently address the challenges of studying Africa and understanding our contemporary world. How to navigate the divergent currents of universalism and relativism? How to critique and transform Western epistemological concepts and theories? How to establish more inclusive bases for intercultural dialogue in conditions of diversity? These are some of the key questions he will tackle in his presentation.

\section{Introduction}

When I first learnt that I had been chosen to deliver this lecture, I thought to myself how unusual it was for ECAS to have a 'local hero'2 as keynote speaker. Fortunately, I am arrogant enough - that's at least what people I don't like say about me - to assume that the International African Institute must have had very good reasons to chart new territory. The problem, however, is that in the meantime I've become a local villain for accepting the honour.

The invitation to be the keynote speaker of a lecture name after Lord Lugard has become something of a mixed blessing in the days of \#mustfall. ${ }^{3}$ I've disappointed many younger and older colleagues both here in Basel and elsewhere by accepting to speak in honour of a man who stands for an objectionable period in African history and in the history of relations between Europe and Africa. ${ }^{4}$ I understand their disappointment and I hope some of what I would like to share with you today will help create a framework within which we can continue this most important conversation.

I am honoured, I am deeply honoured, to deliver this lecture. In fact, I've been relishing this moment from the word go. I have been wondering how sweet the words would sound that would introduce me - and I'm glad Alcinda [Honwana] didn't disappoint me - which aspects of my work would be brought to the attention of the audience, and, most of all, which things I wrote, but never quite understood myself, would finally be explained to me by whoever would introduce me ...

\footnotetext{
${ }^{2} \mathrm{I}$ am based at the University of Basel, where ECAS 2017 took place.

${ }^{3}$ I have in mind the students' campaigns in South Africa against a Rhodes monument on the campus of the University of Cape Town as well as against fees nationwide.

${ }^{4}$ Ahead of the ECAS conference, we held a General Assembly at the Centre for African Studies during which we were mandated by the General Assembly to bring to the attention of the AEGIS Plenary the opposition of most members to the name. I had interesting discussions about this topic with many colleagues, in particular with Melanie Boehi, Julia Büchele, Pascal Schmid, Jacob Geuder, Giorgio Miescher and Veit Arlt. In a sense, the lecture became an extended response to these colleagues.
} 
I know that, after learning that the chairwoman of the Institute, Alcinda Honwana, is a fellow countrywoman of mine, some of the assembled Africanist expertise here will have jumped to the usual conclusions. So let me reassure you: it's not what you are thinking, this is mere coincidence. But I do thank her for the kind introduction and I bow before her own achievements as a scholar who, now that we are at it, holds high the banner of Mozambican, African and, of course, female scholarship across the world. Alcinda's work on youth in Africa (Honwana 2012) has been a major influence on our own work here in Basel and on the career paths of young graduates in Mali and Burkina Faso (Engeler et al. 2017).

\section{The Lugard Lecture as a mixed blessing}

The Lugard Lecture has, in fact, been a poisoned chalice right from the start. I remember that at the first ECAS in London, back in 2005, I was asked to comment on the first Lugard Lecture to be given during the ECAS conference. ${ }^{5}$ I went there bent on causing trouble around the name and the person, just like my younger colleagues here in Basel, and so I dug out every filthy thing I could find about Lord Lugard, like this gem about how he saw Africans:

The typical African ... is a happy, thriftless, excitable person, lacking in self-control, discipline and foresight, naturally courageous, courteous and polite, full of personal vanity, with little of veracity; in brief, the virtues and defects of this race-type are those of attractive children. (Lugard 1922: 69)

I wanted to chastise Emmanuel K. Akyeampong for accepting the invitation to speak under the banner of a man who held such views. But, in the end, I decided not to say anything because, among other reasons, and to my greatest surprise, Akyeampong was introduced by Valentin Mudimbe, the doyen of the African diaspora if there ever was one, who happened to be the chairman of the Council of the International African Institute at the time. If even the man of letters who so convincingly wrote about the invention of Africa and called upon us to challenge the colonial library felt comfortable with the name, who was I to differ? In any case, I drew comfort from the realization that somehow my ability to control myself, to be disciplined and less excitable, was proving the great Englishman wrong. Today, with the benefit of hindsight, I also realize that there was foresight in the decision to shut up, for had I opened my mouth I might never have been considered for a keynote by the International African Institute. And like I say, to be a keynote speaker for the IAI and at ECAS is an honour.

Now, there are serious issues involved here. These are issues which have to do not only with what it means to engage in knowledge production. They also

\footnotetext{
${ }^{5}$ I was asked by the late Patrick Chabal and Ulf Engel. A list of all traceable IAI lectures has been compiled by the IAI and is available at $<$ https://www.internationalafricaninstitute.org/ lectures.html $>$. Emmanuel K. Akyeampong's lecture is available at $<$ https://doi.org/10.3366/afr. $2006.0033>$.
} 
have to do with our schizophrenia as African or Africanist scholars. When you suffer from schizophrenia, loneliness is not your major problem. But it takes a lot of mental strength to learn to manage the double life forced upon you by your commitment to a way of making sense of the world based on conceptual vocabularies that were brought to you by brilliant minds who despised your ancestors or who issued from an imperial culture for which abuse was the language of preference to deal with you, your culture or the cultures you are interested in.

So, what do you do under the circumstances? Do you withdraw into what Samir Amin, the Egyptian scholar, once described as provincialism - i.e. refusing to acknowledge the larger forces that may be responsible for the paradoxes of the world in which we live - or do you find comfort in the realization that those who extoll the virtues of universalism have not quite lived up to it either? Do you, to use Dipesh Chakrabarty's word, the Indian historian, seek to 'provincialize' Europe and celebrate, with Aimé Césaire, the Caribbean poet and politician, the people who invented nothing? Do you frown upon what Mudimbe called the smell of the father (l'odeur du père) and soberly deplore the loss, for good, of Africa? Or do you hold on to an image of a past which may never have been there? Do you ask rhetorically with Spivak, another Indian scholar, whether the subaltern can speak, or should you, as I have suggested recently, ask the sovereign to shut up? Do you, with Chinweizu, Ngugi wa Thiongo and Kwasi Wiredu, call for the decolonization of the African mind, or should you change the focus and call for the decolonization of the European mind? And when you follow suit on this call for the decolonization of minds, what kind of research programme are you going to be standing up for? How are you going to vouch for its intellectual integrity without appearing contradictory? I mean, how do you rebel against something misrepresenting you when you know that your rebellion is intelligible to you and to others because you and those others both know that your rebellion can only be articulated and rendered intelligible within the framework laid down by the conceptual language which misrepresents and oppresses you?

It was Kwame Anthony Appiah, the Ghanaian philosopher, who exposed the ridiculous side of this paradox when he described nativism in African literature as something akin to natives following the Emperor's orders to get dressed, but insisting that the clothes should be made from home-grown cotton (Appiah 1992) ... Whether we like it or not, and in spite of claims to the contrary by those of us who see usefulness in working out Southern epistemologies, de-colonial perspectives or whatever we want to call them, there doesn't seem to be any way in which we could formulate our criticism of so-called Western epistemologies (plural or singular) without falling prey to what philosophers describe as a selfreferential paradox. Is a view from nowhere possible? How can I engage in Western bashing when I know that the intelligibility of what I am doing is to be found in the thing that I reject? Can I describe myself as a sociologist, or social scientist for that matter, even though I have misgivings about the uses to which the discipline has been put in the past? How liberating can a de-colonial project be which is formulated from within the colonial project from which it wishes to escape? And if we can step aside, will we still have cause to rebel? Isn't silence the most de-colonial act, the most radical form of resistance at all? Merely shutting up, not saying anything in order not to be trapped into using contaminated words and languages? But then again, to the extent that shutting up would be an option given us by our oppressors, how much resistance could be read into that? 


\section{Nietzsche and free spirits}

I am already past the first quarter of my time and I realize with dismay that I have not yet said what I am actually up to. I hope, however, that my last thoughts have given you a sense of the direction in which I'm moving. I'm concerned with scholarship in Africa, but also with scholarship about Africa. I am particularly interested in reflecting on the job which we are doing when we claim to be doing African Studies. The issue does not interest me because I need arguments to convince the University of Basel to continue paying for my position. I mean that too, but I'm interested in the issue because the legitimate questions which we can ask about personalities such as Lord Lugard raise further questions about why we study Africa in the first place. We feel uncomfortable about people like Lord Lugard because we associate him with a whole tradition in the study of non-European societies from which we are trying to break free.

I know that this audience will not be impressed to know about how proud I am to serve a university that once employed a great dead white male - he was alive then - by the name of Nietzsche. But I appeal to my posthumous colleague to make my point. Incidentally, God is said to be saying with a contented smile: 'Nietzsche is dead.' Our will to truth conceals our will to ignorance. In other words, if we want to have knowledge - or truth, for that matter - we must seek the company of illusion and falsity: i.e., we must make sense of things ourselves so that we can hold on to the truths which such creations present to us. It was in 'The birth of tragedy', the piece in which he defined art as that which makes life meaningful and tragedy as its highest form making life tolerable, that Nietzsche suggested to us that surviving chaos, and politically incorrectly named keynote lectures, implies constructing a meaningful world. ${ }^{6}$

There is a sense in which engaging in scholarship when you are not European or, to be more inclusive, when you are interested in non-European subjects - is an exercise in coming to grips with cynicism. Reading about the Enlightenment and all the values it expounded is in some ways highly challenging because it makes you wonder why a culture which extolls universal values insists that the path to truth, if ever there was one, must follow signposts written in one conceptual language informed by very local values. It makes you wonder why intelligibility is a function of our ability to make sense of other realities using one particular experience of the world. It makes you wonder why studying Africa must necessarily mean applying theoretical and conceptual resources developed in the so-called minority part of the world, and not also availing oneself of our study of the African continent to help improve our ways of making sense of the world, including making sense of Europe. So, if you don't want to be cynical you must be like the type of philosopher celebrated by Nietzsche, the 'free spirit' (Freigeist), the kind of philosopher who is aware that doing scholarship is like walking at the edge of the abyss, knowing full well that the ground upon which one stands is shaky.

Maybe by assuming that the ground upon which we stand is unstable, and shifting, we are already being cynical. Yet, that is what enables us, I submit to

\footnotetext{
${ }^{6}$ I draw mainly from the highly compelling interpretation of the work of Nietzsche by Rick Mayock (2010).
} 
you, to find our bearings in the world. The fact that we are conscious of the lack of ground beneath us enables us to resist the temptation to think that our ideas and findings represent objective reality. All these 'out of the way things' which happen to us when we look at how the world played evil stepfather with Africa help us search for possible worlds in all the things left unsaid by the conceptual apparatuses which we deploy to elicit meanings from reality. It was Kwasi Wiredu, another Ghanaian philosopher, who called upon us to have the courage to squeeze concepts until they can no longer tell us anything new or intelligible about the world we know, so that by becoming aware of the limits of our world we can begin to understand. The way we then rearrange the world on the basis of the meanings which the concepts can no longer yield would represent our 'will to power'.

\section{Urbane scholarship}

And that is precisely what I would like to define as 'urbane scholarship'. I use this notion in two related ways, but first let me say something about how I see its connection to urban studies. I see African urban settings as spaces made up of technological artefacts. In other words, the urban in Africa - as indeed everywhere else is defined by the high density of technological artefacts. Now, I don't mean this in the obvious sense of such technology as transport means, civil engineering and industrial goods of all sorts. Rather, I define technology as people doing things. ${ }^{7}$

In this sense, then, a motorized vehicle - say, a car - is not that piece of engineering made of metal, wires, plastic, leather and feathers. Rather, a car becomes a car through the work different individuals invest in accomplishing the idea of a car. So, what makes a car a car and lends it its materiality is the job to which people put it in everyday life, the attention which they accord it, the acknowledgement of the constraints which it imposes on individuals and vice versa, the rules and regulations governing its use with special attention being paid not to how cars constrain individuals, but what meaning such constraints have for different individuals as well as how these then have an impact on the nature of social relationships. You see the car as people doing things in accidents, traffic jams, leisurely drives and so on. To put it differently, the idea of the car is accomplished in social situations. My idea of a technological artefact refers to these social situations which are people doing things. It refers to the density of meaning to be found in every single moment of interaction, which, in turn, yields the urban as an object of study.

What is fascinating about the urban in Africa is not that it is dysfunctional, like a normative view of things would have us believe, nor that it is chaotic, hectic and seamless. No. What is fascinating about African urban settings is how good they are at erasing the traces of their own constitution, i.e. how they are able to blur the distinction between routine and creativity so that everyday life becomes a protracted negotiation of the conditions under which things should be done, or should happen. In other words, you don't take anything for granted in these settings, yet to be able to do anything and survive, you must take something for

\footnotetext{
${ }^{7}$ I borrowed this insight from an analytical trick suggested by the American sociologist Howard S. Becker (1998).
} 
granted, whatever that may be. So you need to be smart. You need practical reason - a very important asset in African urban settings. Elsewhere, I described traffic by drawing attention to how this practical reason was deployed. I would like to quote myself:

The common object in traffic is movement. Movement is the overriding moment and it takes place even when nobody is moving. Where there is a traffic jam, movement is diverted to wild gesturing, hooting, risky manoeuvres to signal to others that one wants to move. Focus on movement is expressed by the primary concern of drivers to move forward, i.e. moving in order to move on. Other road users only get right of way if in that way others are able to gain some room for physically moving. A red traffic light where there is no other vehicle is not a red traffic light. And when traffic is dense, any existing traffic light ceases to exist. It is simply a nuisance. In fact, under such circumstances, local knowledge becomes particularly important. So in Maputo, for example, there is this traffic light which only locals can interpret. Those, like me, who did not really know that traffic light, thought that the order in which the lights went up was arbitrary. Sometimes it went green after red and sometimes it went yellow (amber) followed by red twice. As one can easily imagine, the colours had lost their standard meaning there. Locals had their own interpretation which I learned the hard way. Indeed, when red goes up after a quick yellow, then that red means green; green after red twice is yellow, and when yellow shines for longer than five minutes, then, and in between green shines, that green is not green, but red. Actually, I did not really get it myself. At the end of the day, I just concentrated on the behaviour of others. And that is the point, actually, of practical reason. One reacts to local circumstances in ways that come close to what Herbert Simon defined as bounded rationality. (Macamo 2017: 383-4)

So, survival in urban settings in Africa requires smart individuals, people with a high level of social sophistication, people who are unlike Walter Benjamin's 'flaneur' and his fear of being alone, or Georg Simmel's recipient of urban stimuli that make individuals more aware of others while at the same time being less sensitive to them. African urban settings erase the distinction between observer and observed, and heightened sensitivity does not translate into less feeling towards others. Rather, taking the other into account becomes the condition of possibility of life in African urban settings. These settings foster an urbane attitude to life, i.e. a non-normative sophistication of manners that go from being uncouth - and knowing that one is being uncouth - to being polite - and not giving a damn about it.

Now, I said I use this notion of 'urbane scholarship' in two related ways. First of all, urbane scholarship describes a way of being in and dealing with the world. It is how, to fall back on Nietzsche again, 'free spirits' deal with the world. They know there is no solid ground on which to stand - or rather, what is solid about urban settings is only the assumption that everyone makes that the ground is solid. So, 'living the city' consists in working hard to sustain the illusion of certainty for the sake of coming to terms better with the basic, pervasive and insidious instability of urban settings. Secondly, urbane scholarship describes a research field constituted by elusive objects hiding away from our conceptual gazes and constantly resisting our grasp. In this respect, engaging with the urban is to constantly reflect on what makes it possible for us to know. ${ }^{8}$ And that's what African Studies is mostly about.

${ }^{8}$ I elaborate on this in Macamo (2016). 


\section{Understanding the world}

So, here is my grand point and, perhaps, the point I want to convey to this conference. We don't study the urban for the sake of the urban. We study it in order to know how to study it. In other words, the challenge is a methodological one, just like with African Studies in general. It is true that we study Africa with practical goals in mind. We want to contribute to the elimination of poverty, political strife, disease and many more social ills. Yes. But there is more to it. We study Africa because we want to know how to study Africa. That's scholarship. Scholarship is not defined solely by the conclusions we can draw about our study objects. It is also, and perhaps more fundamentally, defined by the ability to reflect on the best way to organize our ways of knowing.

Now, it is my belief that African Studies as a field gives us a privileged opportunity to engage in this. Time and again we are confronted with the inadequacy of our theoretical and conceptual tools when we try to make sense of things in this most fascinating continent. African phenomena challenge us to be critical of those tools and, in so doing, to take care not to reduce what we study to what falls within the semantic fields of our concepts, but rather to go beyond them and give the improbable and the unintelligible the benefit of the doubt.

Most of all, African Studies implies an ethical commitment. It does not imply an ethical commitment towards the poor and the wretched of the earth, to use Frantz Fanon's poignant words. It implies an ethical commitment towards knowledge because knowledge is responsibility. Africa is not what it is because of what it is like. Africa is what it is because of what the world is like, and vice versa. So we study Africa to understand the world. In fact, that's our intellectual agenda here at the Centre for African Studies and we are very proud to work on this agenda, and grateful to the university leadership for giving us room to do so. ${ }^{9}$

But that's a huge responsibility. And it starts with that most 'African' of all virtues, namely acknowledging and showing respect to our ancestors. Yes, Lord Lugard is my ancestor, however pale he may have been. If I commit myself to knowledge production I must have the courage and sense of responsibility to accept him, and his blunders and sins, as part of the legacy that enables me to see things the way I see them today, both critically and in a celebratory mood. There is no reason why a name that elicits shame should not be used as an occasion to think about what disturbs us, what we don't want to be like, what we want to distance ourselves from. Lord Lugard should not fall because if he does he may tear down most of what makes it possible for us to be critical of him. Or I might just as well silence myself, knowing full well that my silence is rendered intelligible by that which I reject. ${ }^{10}$

\footnotetext{
${ }^{9}$ The Centre for African Studies at the University of Basel has developed a new strategy based precisely on this motto: 'Studying Africa, Understanding the World'.

${ }^{10}$ I struggle here with a very difficult distinction between what is political and what is methodological. I wonder if there is any way in which we can engage with the intellectual production of individuals without paying attention to their ethical values. I wish this were possible, but then again I have no idea what the consequences would be in the social sciences. Can I remain indifferent to someone who is racist in his views while acknowledging the validity of whatever else they may have found out through research?
} 
Lord Lugard should stand so that pigeons can do all the things we would like to do to him, but most of all so that we can stand on him, because we do stand on him, and look even taller because great people are willing to shoulder responsibility, unlike some of the darker sides of the Enlightenment which are usually the target of our criticism. They often shunned responsibility, the most important of which continues to be this condescending view of Africa as a continent which is the victim of its own failures, this arrogance of severing the troubles of the continent from the history that created them.

As a scholar of African origin I see myself as the beneficiary of moral luck. The evil things which other people did to me or to my people do not make me a better individual. What makes a better individual out of me is my willingness to take up responsibility for the decisions which I take. I do not become a better moral being by asking others to do what I think is morally right. I can only forgive, or refuse to forgive. It is up to the others to decide whether the pain which they inflict on others on account of their decisions to honour their own is worthwhile. ${ }^{11}$ Recently, I was talking about these things with several friends and colleagues. Two of them, from Nigeria, Professors Omotayo Oloruntoba-Oju and Taiwo Oju, drew my attention to a poem by Derek Walcott, the Caribbean poet, 'A far cry from Africa', ${ }^{12}$ in which, after a line that reads 'The violence of beast on beast is read / as natural law, but upright man / seeks his divinity by inflicting pain', it goes on to say:

I who am poisoned with the blood of both,

Where shall I turn, divided to the vein?

I who have cursed

The drunken officer of British rule, how choose

Between this Africa and the English tongue I love?

Betray them both, or give back what they give?

How can I face such slaughter and be cool?

How can I turn from Africa and live?

\section{Conclusion}

So let me end this address with a little confession. I've always been an underground critic of keynote speeches which fail to set the tone and the mood for the conference. My expectations were set so high, of course, because I never thought I would ever be asked to deliver one. There is an enigmatic - and, for some, arrogant - sentence penned by Nietzsche in a letter to another posthumous colleague, the culture and art historian Jacob Burckhardt. I would like to share it with you in the hope of making up for any failure to unleash your enthusiasm in my keynote.

He was explaining his resignation from the university, and I quote him:

\footnotetext{
${ }^{11}$ Here again I am torn, and Julia Büchele, my colleague at the Centre for African Studies in Basel, painfully drew my attention to this problem. What if I were a 'scholar of African Studies' who does not come from Africa? How would I respond to this challenge? Is moral condemnation, in my terms here, only legitimate if it is voiced by English scholars of African Studies?

${ }^{12}$ Available at <https://www.poets.org/poetsorg/poem/far-cry-africa $>$.
} 
In the end, I would rather be a Professor in Basel than being God; my problem is that I have not dared to drive my private selfishness so far as to abandon the creation of a world just for the sake of my private selfishness. ${ }^{13}$

Here in Basel, by the way, it is hard to be modest when you're so great!

We, the African Studies community, cannot afford to let our selfishness stand in the way of a better understanding of the world. And the urban and the urbane qualities the study of Africa fosters in us can ensure that for three days we become urbane scholars in Basel for the sake of the world.

I thank you for your attention and wish us all a great world-making conference!

\section{References}

Appiah, K. A. (1992) In my Father's House: Africa in the philosophy of culture. Oxford: Oxford University Press.

Becker, H. S. (1998) Tricks of the Trade: how to think about your research while you are doing it. Chicago IL: Chicago University Press.

Engeler, M., N. Steuer and E. Macamo (eds) (2017) Dealing with Elusive Futures: university graduates in urban Africa. Bielefeld: Transcript Verlag.

Halter, M. (2015) 'Lieber Professor in Basel ...', Tagesanzeiger, 3 February $<$ https://www.tagesanzeiger.ch/kultur/buecher/Lieber-Professor-in-Basel-als-Gottim-Himmel/story/11869517>.

Honwana, A. (2012) The Time of Youth: work, social change, and politics in Africa. London: Kumarian Press.

Lugard, F. D. (1922) The Dual Mandate in British Tropical Africa. 5th edition. London: William Blackwood and Sons.

Macamo, E. (2016) 'Before we start: science and power in the constitution of Africa' in M. Ramutsindela, G. Miescher and M. Boehi (eds), The Politics of Nature and Science in Southern Africa. Basel: Basler Afrika Bibliographien.

Macamo, E. (2017) 'Traffic and order: negotiating the meaning of technological artefacts in an African urban setting' in M. Verne, P. Ivanov and M. Treiber (eds), Körper Technik Wissen - Kreativität und Aneignungsprozesse in AfrikaIn den Spuren Kurt Becks. Berlin: Lit Verlag.

Mayock, R. (2010) 'Perspectivism and tragedy: a Nietzschean interpretation of Alice's adventures' in R. B. Davis (ed.), Alice in Wonderland and Philosophy: curiouser and curiouser. Hoboken NJ: John Wiley and Sons.

\footnotetext{
${ }^{13}$ The original reads as follows: 'Zuletzt wäre ich viel lieber Basler Professor als Gott; aber ich habe es nicht gewagt, meinen Privat-Egoismus so weit zu treiben, um seinetwegen die Schaffung einer Welt zu unterlassen' (quoted in Halter 2015).
} 